Www.ijbpas.com

\title{
COMPARATIVE IN-VITRO ANTI-INFLAMMATORY ACTIVITY OF GOMUTRA SADHITA TRIPHALA KWATHA AND GOMUTRA SADHITA TRIPHALA ARKA
}

\section{PATHANIA $S^{1 *}$, JHA LL $^{2}$, MISHRA AK ${ }^{3}$ AND RAGHUVEER H ${ }^{4}$}

1: PG Scholar, Department of Rasa shastra \& Bhaishajya kalpana, Parul Institute of Ayurveda, Parul University, Vadodara, Gujarat

2: Professor \& Principal, School of Pharmacy, Parul University, Vadodara, Gujarat

3: Professor, Department of Rasa shastra \& Bhaishajya kalpana, Parul Institute of Ayurveda,

Parul University, Vadodara, Gujarat

4: Professor \& HOD, Ashwini Ayurvedic Medical College \& PG Centre, Davanagere, Karnataka

*Corresponding Author: Dr. Sahil Pathania

Received $12^{\text {th }}$ Dec. 2021; Revised $14^{\text {th }}$ Jan. 2022; Accepted $7^{\text {th }}$ Feb. 2022; Available online $5^{\text {th }}$ March 2022

https://doi.org/10.31032/IJBPAS/2022/11.3.1081

\begin{abstract}
Inflammation in Ayurveda can be correlated with Shotha. There are formulations in Ayurveda which are indicated in Shotha. Some of the formulations remained untouched. Here one formulation Gomutra Sadhita Triphala kwatha in Ayurvedic texts is explained in the Shotha conditions. But due to some lacunas in Kwatha kalpana the dosage form was changed into Arka. Then both kalpanas were taken for the in-vitro anti-inflammatory study. Protein denaturation is documented cause of inflammation. So change in protein denaturation suggests changes in inflammation. If protein denaturation is inhibited it is told that inflammation can also be inhibited. Protein denaturation inhibition was used to assess anti-inflammatory efficacy in vitro. Bovine serum albumin was used in the protein denaturation inhibition study at different concentrations. After the study it was found that both Kwatha and Arka have anti-inflammatory properties as percentage of inhibition was found to be good at different concentrations. Gomutra Sadhita Triphala kwatha was having high percentage of inhibition than the Gomutra Sadhita Triphala arka.
\end{abstract}

Keywoerds: Kwatha, Arka, Anti-Inflammatory, In-Vitro Study 


\section{INTRODUCTION}

Inflammation is a defence mechanism that enables the body to protect itself against infection, burn, toxic chemical allergens or any other harmful stimuli. Heat, redness, discomfort, swelling, and disrupted physiological activities are all signs of inflammation in response to injury, sickness, or destruction. It's a complicated process that's usually linked to pain, and it includes things like increased vascular permeability and protein denaturation. Protein denaturation is a well-known cause of inflammation. The confrontation of a protein is solely dependent on weak valence forces. Hence it can be disrupted easily by a variety of physical and chemical agents. The process is known as denaturation. Protein molecules play a crucial role in the functioning of living systems. Most importantly, the majority of proteins have a very specialized role to play. Protein structure is what dictates this specificity and the three-dimensional structure is particularly important. The protein loses its functionality when this unique three-dimensional structure is broken, and it is considered to have experienced denaturation. The interactions that determine the tertiary structure of proteins, such as hydrogen bonding, are not as strong as covalent chemical bonds. Because these interactions are rather weak, they can be disrupted with relatively modest stresses1. Non-Steroidal AntiInflammatory Drugs (NSAIDs) are the most often used drugs to treat inflammatory diseases. The greatest disadvantage in the presently available potent synthetic antiinflammatory drug lies in their toxicity and reappearance of symptoms after discontinuation.2 Inflammation in Ayurveda is known by different names in different contexts namely, shotha, shopha, utsedha and samhata. While modern medicine regards inflammation as a symptom or rather as the body's natural healing response to wounds. Ayurveda treats the concept of inflammation as symptom of disease, an independent disease and complication of diseases. The natural products today symbolizes safer in contrast to the synthetic drug that are regarded as unsafe to human environment. In Ayurvedic texts there are many shothahara (anti-inflammatory) formulations available. One such drug Gomutra Sadhita Triphala Kwatha is mentioned in Bhaishajya ratnavali.3 But due to the less shelf life i.e.24 hours4, high dose of aministration5 and also due to high administration dose Kwatha is not palatable. So, the modification of Kwatha is done into Arka as it is having less administration dose and more shelf life6. 
So, study is planned to prepare Kwatha as well as Arka and subjected to in-vitro antiinflammatory activity by Protein Denaturation Inhibition Method.

\section{MATERIALS \& METHODS}

\section{Collection of Raw Materials:}

Haritaki, bibhitaki and Amalaki were collected from Aimil Pharmaceuticals Pvt.
Ltd. Nalagarh (H.P.) The Gomutra for the study was collected from Gaushala in Goraj, Waghodia, and Vadodara Gujarat.

\section{Preparation of Kwatha and Arka:}

Kwatha and Arka for in-vitro study was prepared in the GMP certified Parul Ayurved Pharmacy. The final products received are taken for the in-vitro study.

Table No 1: Raw Drug Quantity for Kwatha

\begin{tabular}{|c|c|c|c|c|}
\hline S. No. & Drugs & Latin Name & Part used & Quantity \\
\hline 1. & Haritaki & Terminalia chebula Retz. & Dried fruit pericarp & 1part \\
\hline 2. & Bibhitaki & Terminalia bellerica Roxb. & Dried fruit pericarp & 1part \\
\hline 3. & Amalaki & Emblica officinalis Gaertn. & Dried fruit & 1part \\
\hline 4. & Gomutra & Cow's urine & - & 16parts \\
\hline
\end{tabular}

Table No 2: Raw drug Quantity for Arka

\begin{tabular}{|c|c|c|c|c|}
\hline S. No. & Drugs & Latin Name & Part used & Quantity \\
\hline 1. & Haritaki & Terminalia chebula Retz. & Dried fruit pericarp & 1part \\
\hline 2. & Bibhitaki & Terminalia bellerica Roxb. & Dried fruit pericarp & 1part \\
\hline 3. & Amalaki & Emblica officinalis Gaertn. & Dried fruit & 1part \\
\hline 4. & Gom utra & Cow's urine & - & 10parts \\
\hline
\end{tabular}

IN-VITRO

DENATURATION METHOD

Compounds that prevent protein denaturation in vitro could be employed as anti-inflammatory drugs. The antiinflammatory effect of a sample was performed by using serum albumin. The bovine serum albumin assay aims to eliminate the usage of live specimens in the drug development process as much as feasible. When Bovine serum albumin is heated, it undergoes denaturation (heat induced protein denaturation) and express antigens associated with type 3 hypersensitivity reactions, which can be related to the inflammation.
Materials required:

Bovine serum Albumin

Hydrochloric acid-1N

$>$ Phosphate buffer

Distilled Water

Procedure:

Different concentrations of sample (0.78$50 \mu \mathrm{L}$ ) were taken directly from the sample and were used for the study. The test control consists of $0.45 \mathrm{~mL}$ of Bovine serum albumin and $0.05 \mathrm{~mL}$ of distilled water. The test solutions consist of $0.45 \mathrm{~mL}$ of Bovine serum albumin and $0.05 \mathrm{~mL}$ of different concentrations of sample. Product control consists of $0.45 \mathrm{~mL}$ of distilled water and different concentrations of sample. All the above solutions were 
adjusted to $\mathrm{pH} 6.3$ using $1 \mathrm{~N} \mathrm{HCl}$. The samples were incubated at $37^{\circ} \mathrm{C}$ for 20minutes and the temperature was increased to $57^{\circ} \mathrm{C}$ for 3 minutes. After cooling, $2.5 \mathrm{ml}$ of phosphate buffer was added to the solutions. The absorbance was measured using UV-VISIBLE Spectrophotometer at $660 \mathrm{~nm}$ (Cary 60 UV-visible, Agilent Technologists)

- TEST SOLUTION(0.5 ML) : $0.05 \mathrm{ml}$ of test solution $+0.45 \mathrm{ml}$ of Bovine serum albumin

- Test Solution1: $0.05 \mathrm{ml}$ of Gomutra Sadhita Triphala kwatha and $0.45 \mathrm{ml}$ of Bovine serum albumin

- Test solution2: $0.05 \mathrm{ml}$ of Gomutra Sadhita Triphala arka and $0.45 \mathrm{ml}$ of Bovine serum albumin

- TEST CONTROL SOLUTION (0.5ML): $0.05 \mathrm{ml}$ of distilled water $+0.45 \mathrm{ml}$ of Bovine serum albumin

- PRODUCT CONTROL SOLUTION (0.5ML): $0.05 \mathrm{ml}$ of test solution and $0.45 \mathrm{ml}$ of distilled water.

- Product control solution1- $0.05 \mathrm{ml}$ of test solution 1 and $0.45 \mathrm{ml}$ of distilled water.

- Product control solution2-0.05ml of test solution 2 and $0.45 \mathrm{ml}$ of distilled water.

CALCULATION
The percentage inhibition of protein denaturation can calculated as $\%$ inhibition $=100-[(($ optical density of test solution- optical density of product control) $\div$ optical density of test control)) $\times 100$ ]

- The optical density (OD) was measured by spectrophotometry.

\section{Interpretation}

The anti-inflammatory efficacy of a drug can be expressed in terms of half maximal inhibition concentration (IC50). It is a measure of the potency of a substance in inhibiting a specific biological or biochemical function. This quantitative measure indicates how much of a particular drug or other substance (inhibitor) is needed to inhibit a given biological process (or component of a process, i.e. an enzyme, cell, cell receptor or microorganisms) by half. The values are typically expressed as molar concentration. It is commonly used as a measure of antagonist drug potency. According to the FDA, IC50 represents the concentration of a drug that is required for $50 \%$ inhibition in-vitro. IC50 can be used to compare the potency of two antagonists. The lower the IC50 value, the stronger the inhibitor is. The IC50 values of the investigational products were calculated using ED50 Plus V1.0 software and were tabulated.

\section{RESULT:}


Table No 3: Sample: GTA (OD of test control=0.1708)

\begin{tabular}{|c|c|c|c|}
\hline $\begin{array}{c}\text { Concentrations } \\
(\mu \mathrm{l} / 3 \mathrm{ml})\end{array}$ & OD of test solution & OD of Product control & \% of inhibition \\
\hline $\mathbf{0 . 7 8}$ & $\mathbf{0 . 1 5 6 7}$ & $\mathbf{0 . 0 2 1 2}$ & 20.66745 \\
\hline 1.56 & $\mathbf{0 . 1 5 7 3}$ & $\mathbf{0 . 0 3 7 6}$ & $\mathbf{2 9 . 9 1 8 0 3}$ \\
\hline 3.125 & $\mathbf{0 . 1 5 7 9}$ & $\mathbf{0 . 0 5 7 4}$ & $\mathbf{4 1 . 1 5 9 2 5}$ \\
\hline 6.25 & $\mathbf{0 . 1 6 8 8}$ & $\mathbf{0 . 1 2 0 8}$ & $\mathbf{7 1 . 8 6 6 9 6}$ \\
\hline 12.5 & $\mathbf{0 . 1 6 3 3}$ & $\mathbf{0 . 1 2 2 9}$ & 76.3466 \\
\hline 25 & $\mathbf{0 . 1 6 3 3}$ & $\mathbf{0 . 1 2 6 6}$ & $\mathbf{7 9 . 8 0 0 9 4}$ \\
\hline 50 & $\mathbf{0 . 1 5 6 3}$ & $\mathbf{0 . 1 3 3 5}$ & $\mathbf{8 6 . 6 5 1 0 5}$ \\
\hline
\end{tabular}

Table No 4: Sample: GTK (OD of test control=0.1708)

\begin{tabular}{|c|c|c|c|}
\hline $\begin{array}{c}\text { Concentrations } \\
(\mu \mathrm{l} / 3 \mathrm{ml})\end{array}$ & OD of test solution & OD of Product control & \% of inhibition \\
\hline $\mathbf{0 . 7 8}$ & $\mathbf{0 . 1 5 8 2}$ & $\mathbf{0 . 0 2 9 1}$ & $\mathbf{2 4 . 4 1 4 5 2}$ \\
\hline 1.56 & $\mathbf{0 . 1 5 6 5}$ & $\mathbf{0 . 0 4 5 3}$ & $\mathbf{3 4 . 8 9 4 6 1}$ \\
\hline 3.125 & $\mathbf{0 . 1 5 3 4}$ & $\mathbf{0 . 0 6 0 2}$ & $\mathbf{4 5 . 4 3 3 2 6}$ \\
\hline 6.25 & $\mathbf{0 . 1 5 4 4}$ & $\mathbf{0 . 1 2 6 7}$ & $\mathbf{8 3 . 7 8 2 2 0}$ \\
\hline 12.5 & $\mathbf{0 . 1 5 4 0}$ & $\mathbf{0 . 1 2 7 1}$ & $\mathbf{8 4 . 2 5 0 5 9}$ \\
\hline 25 & $\mathbf{0 . 1 4 7 6}$ & $\mathbf{0 . 1 3 0 8}$ & $\mathbf{9 0 . 1 6 3 9 3}$ \\
\hline 50 & $\mathbf{0 . 1 4 4 3}$ & $\mathbf{0 . 1 3 2 6}$ & $\mathbf{9 3 . 1 4 9 8 8}$ \\
\hline
\end{tabular}

Table No 5: IC $_{50}$ Value calculated

\begin{tabular}{|c|c|}
\hline Investigational Product & $\mathrm{IC}_{50}$ \\
\hline Gomutra Sadhita Triphala Arka & $11.81 \mu \mathrm{l} / 3 \mathrm{ml}$ \\
\hline Gomutra Sadhita Triphala Kwatha & $7.56 \mu \mathrm{l} / 3 \mathrm{ml}$ \\
\hline
\end{tabular}

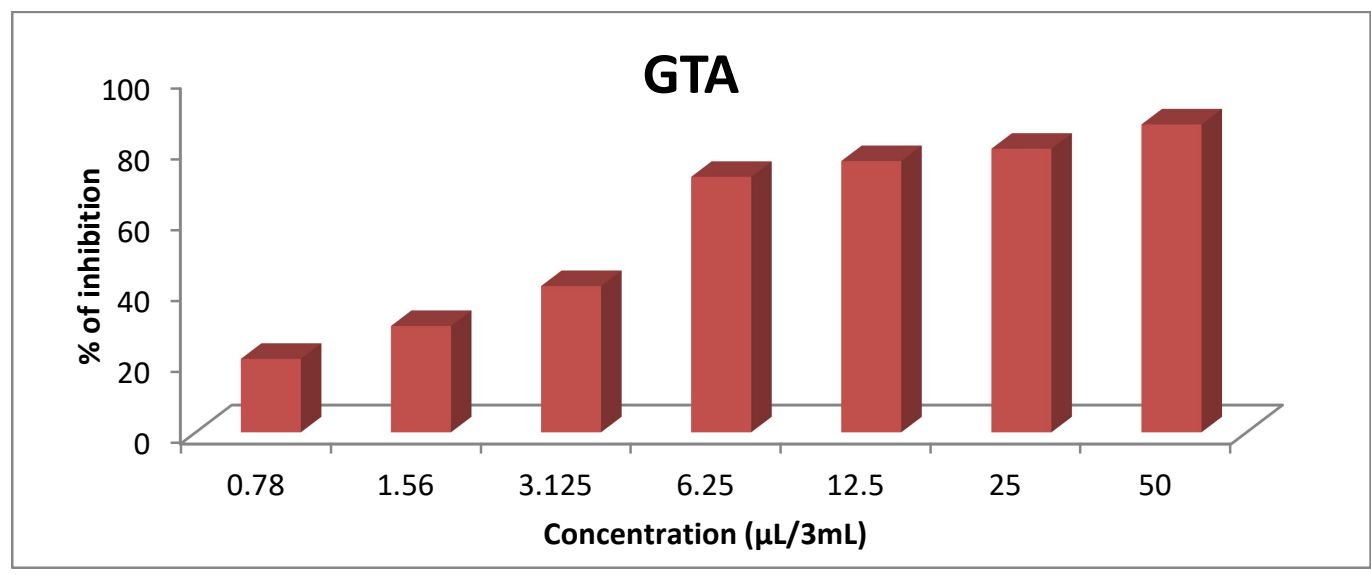

Figure no. 1

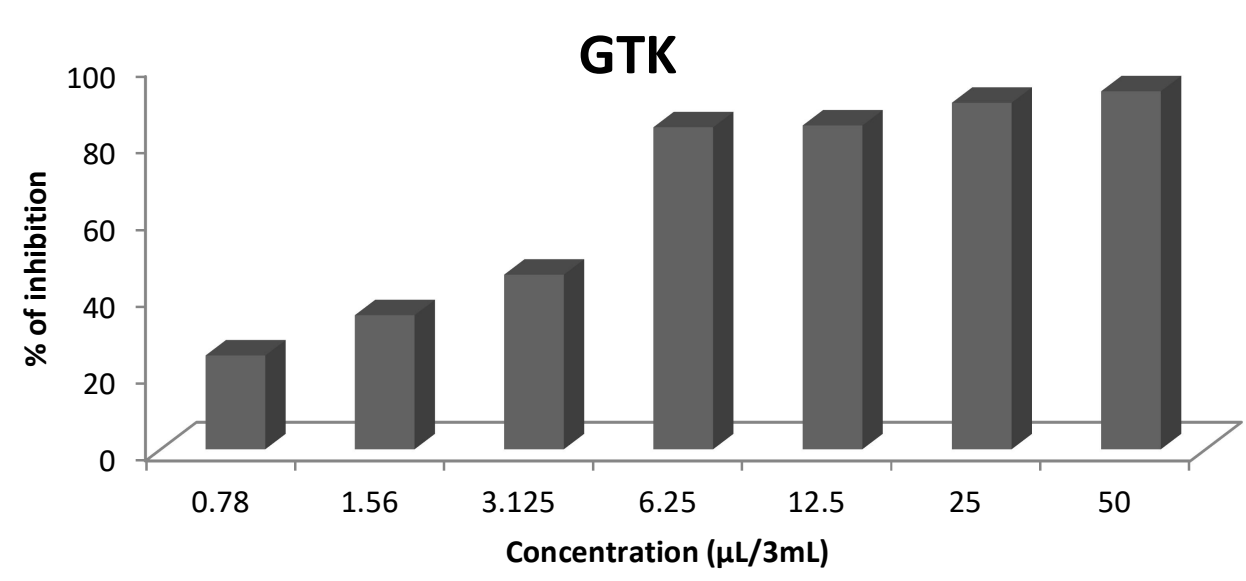

Figure no. 2 


\section{DISCUSSION}

Denaturation of proteins has an unpredictable mechanism which includes modification in electrostatic hydrogen, hydrophobic and disulphide bonding. ${ }^{7}$ Denaturation of protein causes the production of auto antigens in conditions such as rheumatic arthritis, cancer and diabetes which are conditions of inflammation. Hence, by inhibition of protein denaturation inflammatory activity can be inhibited. ${ }^{8}$ In the present study, two different formulations i.e. Kwatha and Arka are prepared from the same drugs and comparative study was done. All the drugs in the formulations are proved to be antiinflammatory. But to some lacunas in Kwatha Kalpana dose modification was done into Arka. These drugs are having the volatile principles in them and their individual Arka are also mentioned in the texts so the modification was done into Arka form. Gomutra used in the study was freshly collected and brought to the pharmacy in the morning. This Gomutra was strained using the double layered cloth to remove the impurities. Then this filtered Gomutra was taken for testing some analytical parameters like $\mathrm{pH}$, refractive index, specific gravity. Next morning Gomutra was again collected from the same place and same cow and bought in the pharmacy. Again filtered and run for the same analytical tests. The values of analytical parameters were nearly similar and this Gomutra was then taken for the preparation of the Kwatha and Arka. In Kwatha Kalpana, the water is mentioned as Drava dravya (liquid media) but here instead of water Gomutra was taken as Drava dravya (liquid media). In Arka Kalpana, there are differences in opinion on the amount of water to be taken. So here method as directed in $\mathrm{AFI}^{9}$ was followed i.e. 10parts of Drava (liquid) to be taken. Here also Gomutra was taken as Drava dravya instead of water. Denaturation of proteins is the well documented cause of inflammation. The compounds that inhibit the denaturation of protein may be used as anti-inflammatory agents. The antiinflammatory effect of drug can be expressed in terms of half maximal inhibition concentration (IC50) by calculating the percentage of inhibition. It is said lower the IC50 value, stronger the inhibitor. From the above calculations it is seen that both the drugs are having the antiinflammatory properties. Arka shows maximum of $86 \%$ of inhibition whereas Kwatha shows $93 \%$ of inhibition. The IC50 value of Kwatha is also less than the Arka. This may be due to the reason that Arka is distillation of drugs so it contains only the volatile principles. But in Kwatha apart from volatile principles other active 
ingredients may be present in the liquid that may be having the anti-inflammatory properties.

\section{CONCLUSION}

From the above study it is concluded that both the drugs are having the antiinflammatory properties. The IC50 value of Kwatha is $7.56 \mu \mathrm{l} / 3 \mathrm{ml}$ and for Arka is $11.81 \mu \mathrm{l} / 3 \mathrm{ml}$. as Kwatha is having the lower value of inhibition concentration so it is stronger inhibitor than the Arka. But Arka is also having the good percentage of inhibition and it can also be used in the treatment of inflammation. And further studies can be conducted with the synthetic drugs for comparing their antiinflammatory activity.

\section{REFERENCES}

[1] Mizushima Y, Kobayashi M. Interaction of anti-inflammatory drugs with serum proteins, especially with some biologically active proteins. Journal of Pharmacy and Pharmacology. 1968 Mar 1; 20(3):169-73.

[2] Chawla A S et al, Plant antiinflammatory agents, J Sci Ind Res 1987; 46: 214-23

[3] Kaviraj Govind Das Sen, Bhaishajya ratnavali by Prof Siddhi Nandan Mishra, Edition 2016, Chaukhambha Surbharati
Prakashan, Varanasi, Chapter 42, Page no 770

[4] Sharangdhar Samhita translated in English by Prof. K. R. Murthy, Chaukhambha Orientalia, Varanasi, Reprint Edition 2017, Madhyam khanda, Chapter 2, Page no. 56

[5] Sharangdhar Samhita translated in English by Prof. K. R. Murthy, Chaukhambha Orientalia, Varanasi, Reprint Edition 2017, Madhyam khanda, Chapter 2, Page no. 56

[6] Lankapati Ravana, Arkapraksha translated by Dr. Indradev Tripathi, Chaukhambha Krishnadas Academy, Varanasi, 1995, Chapter no. 1, Page no. 9

[7] Ssen $\mathrm{S}$ et al . in vitro antiinflammatory activity of Amaranthus caudatus L leaves. Indian J Nat Prod Resour. 2015; $6: 326-9$

[8] Sangeetha $\mathrm{G}$ et al in vitro antiinflammatory activity of different parts of Pedalium murex (L.) Int $\mathbf{J}$ Herb Med. 2016; 4:31-6

[9] The Ayurvedic Formulary of India, Government of India, Ministry of Health and Family Welfare, Department of Ayush, First Edition, 2011, Volume 3, Page no. 3 